\title{
Development of Mobile based Application for Heritage and Piligrimage Sites in India
}

\author{
G. Vinothini, R. Priya, S. Jayanthy
}

\begin{abstract}
The purpose of this paper is designed to search for the subjective and objective aspects of tourism services as a part of an overall pilgrimage experience. The aim of this paper is to determine and review the respondents' opinion regarding the general image of the temple and overall satisfaction towards each factors of big temple which has historic and cultural significance for some and is a venue of shrine pilgrimage for others. The paper will lead to a better understanding of the factors that contribute to the tourist experience's enhancement and thus draw more visitors.
\end{abstract}

Keywords: Attractions, Pilgrimage, Satisfaction level, Temple, Tourism, Tourist

\section{INTRODUCTION}

The most ancient type of tourism is considered religious tourism. As a growing trend, it has great potential that would benefit from academic progress and applied changes. Every year, around 240 million people travel to several major destinations for pilgrimages, especially Christians, Muslims and Hindus[1]-[4]. This remains one of the least discussed tourist activities in the world of modern tourism, given the high number of people involved in religious tourismThere are two distinct dimensions of India's religious tourism: the faith of the domestic visitor, who has a spiritual connection to the religious sites; the other is the ' international ' tourist, who belongs to different religions, regions or nations, for whom the religious site is the ' new ' element, a sprtitual experience different from their own.

\section{REVIEW OF LITERATURE}

Mario Katic (2014) explores that this paper describes and considers the nature of travel behaviour, its emic meaning to pilgrims and its connection to religious tourism and it reveals the significant influence on how we define the participants as pilgrims, tourist or pilgrimage and tourist[5]-[9].

Brohman (1996) thought that the countries of the third world should follow proper tourism planning after consulting local people and using investment and income related to tourism for the benefit of the local community.

Revised Manuscript Received on December 11, 2019

G. Vinothini, Department of Science and Humanities, Bharath Institute of Higher Education and Research, Chennai , India. Email: gvinothinibcom@gmail.com

R. Priya, Department of Science and Humanities, Bharath Institute of Higher Education and Research, Chennai , India. Email: rathi_priya83@yahoo.com

S. Jayanthy, Department of Science and Humanities, Bharath Institute of Higher Education and Research, Chennai , India. Email: Sjayanthy0903@gmail.com
Md. Iqbal Sultan (2015) evaluate tourism infrastructure (i.e. transport, hotel etc.), economic significance of Religious Tourism and focus on environmental problems due to tourism development. Besides this, some suggestions have also been given to promote better tourism.

Xintong, Jü; Yuhui, Yang (2014), suggested that the government should change its thoughts, consider and plan Chongqing religious cultural tourism from a macro-tourism perspective, incorporate different resources and plan management as a whole. At the same time, religious groups should also play an important role in social spiritual tourism

Noga Collins-Kreiner (2010) discusses the reality that Pilgrimage is one of the human world's basic and oldest population mobility and has broad implications: political, personal, cultural and economic. Geographical pilgrimage work is analyzed in this journal, with reference to related results from neighboring disciplines.

\section{OBJECTIVES}

1. To analyse the various purpose of tourist visiting big temple.

2. To analyse the facilities offered at the premises to the tourist.

3. To analyse the satisfaction level of the tourist visiting the temple.

\section{A. Scope}

The study measures the attitude and behaviour of tourists visiting big temple, Thanjavur. From this study, we can analyse the cultural heritage, Potential usage of big Temple by tourism department. Attitude, Perception \& Satisfaction of tourists visiting the temple. This survey was conducted from March 16 to April 16, 2016.

\section{B. Limitations}

1. The study is confined only in perspective of big temple and it may not be applicable to other tourist spots

2. The preferences of the tourist may vary with the time and economic conditions of the tourists. 


\section{Development of Mobile Based Application for Heritage and Piligrimage Sites in India}

3. The data was collected within one-month time period.

\section{RESEARCH METHODOLOGY}

\section{A. Statement of the Problem}

Tourism has grown 25 percent in the past 10 years with the forecast of 1,500 million international arrivals by 2020 , more than double the level at the moment. Service quality in its long journey has reached several new dimensions, but literature related to the quality of religious service is very low[10]-[12].

This work is an attempt to find resources to examine pilgrims ' problems and determine the quality of religious service in Big Temple, Tanjore.

\section{B. Data analysis and interpretation}

In the present scenario preferences among tourist various from one person to another person. So, some dimensions have been used to find those preferences such as frequency analysis of demographic variables.

\begin{tabular}{|c|c|c|c|}
\hline Veribles & Cotay ofy & Frequency & \% frequency \\
\hline \multirow[t]{2}{*}{ Gender } & Male & 153 & $6 !$ \\
\hline & Fenale & 98 & 39 \\
\hline \multirow[t]{4}{*}{ Age } & 11.20 yeass & 18 & 7.2 \\
\hline & $21 \cdot 30$ yess & 182 & 72.5 \\
\hline & 31.40 reass & 37 & 14.7 \\
\hline & Abore 40 rezs & 14 & 5.6 \\
\hline \multirow{2}{*}{ Jeital watns } & Single & 212 & 845 \\
\hline & Meried & 39 & 15.5 \\
\hline \multirow[t]{4}{*}{ Family Members } & $t_{b} \infty 2$ & 7 & 2.8 \\
\hline & 34 & 187 & 74.5 \\
\hline & 56 & $4 !$ & 16.3 \\
\hline & Abere 6 & 16 & 6.4 \\
\hline \multirow[t]{4}{*}{ Location } & Taspilades & 220 & 87.6 \\
\hline & Andhra Padesh & 20 & 8 \\
\hline & Retala & 9 & 3.6 \\
\hline & Wodhy Prodesh & 2 & 0.8 \\
\hline \multirow[t]{4}{*}{ Salary } & $10000-25000$ & 60 & 23.9 \\
\hline & $26000-40000$ & 23 & 9.2 \\
\hline & $41000-50000$ & 122 & 48.6 \\
\hline & Abore 50000 & 20 & 8 \\
\hline \multirow[t]{2}{*}{ Pugose of the risit } & Lasite & 189 & 729 \\
\hline & Rerreatict & 7 & 75.7 \\
\hline
\end{tabular}

Table - 1 Frequency Investigation Of Demographic Variables

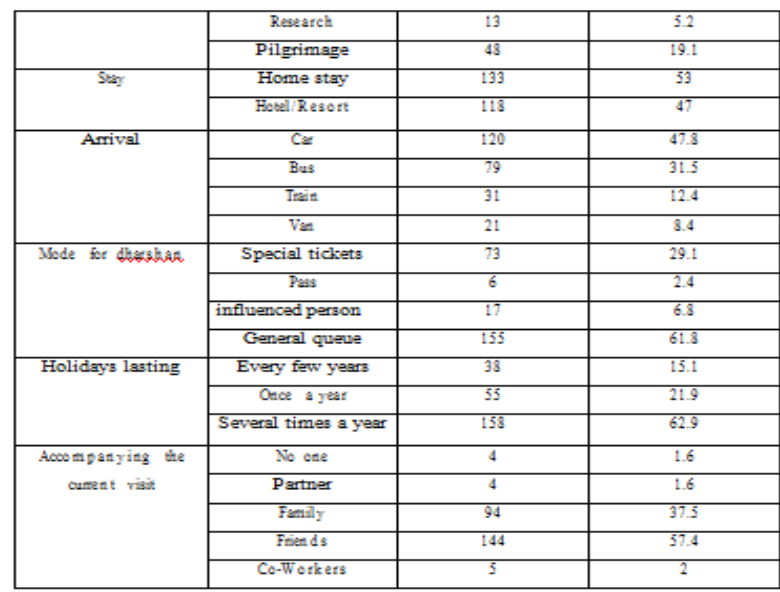

Above data shows that $61 \%$ are male and $39 \%$ are female. It has been inferred that many tourists preferred general queue for Swamidharshan. Many tourists opined that their purpose of tour is for leisure. Large number of People from Tamilnadu visited big temple when comparing other states. Many tourists preferred home stay. It has been inferred that many visitors tour several times a year.

\begin{tabular}{|c|c|c|c|}
\hline Variables & Cotay ofy & Frequency & $\%$ frequency \\
\hline \multirow{3}{*}{$\begin{array}{l}\text { Swamidharghan in } \\
\text { temple }\end{array}$} & Fighly sesisfied & 168 & 66.9 \\
\hline & Sesisfed & 82 & 32.7 \\
\hline & Nentral & t & 0.4 \\
\hline \multirow{4}{*}{$\begin{array}{l}\text { Quality of } \\
\text { prasadhem }\end{array}$} & Fishly sesisfied & 154 & 61.4 \\
\hline & Sesisfed & 62 & 24.7 \\
\hline & Nentral & 29 & 11.6 \\
\hline & Disastisfied & 6 & 24 \\
\hline \multirow{3}{*}{ Basic facility } & Fighly sefisfied & 114 & 45.4 \\
\hline & Sesisfied & 106 & 42.2 \\
\hline & Neutral & 31 & 12.4 \\
\hline \multirow{5}{*}{ Service of the guide } & Fyatly esisfied & 13 & 5.2 \\
\hline & Sesisfed & 141 & 56.2 \\
\hline & Nentral & 83 & 33.1 \\
\hline & Disastiafied & 12 & 4.8 \\
\hline & Fyblily Dassatisfied & 2 & 8 \\
\hline \multirow{4}{*}{ Service of the priest } & Highly sefisfied & 15 & 6.0 \\
\hline & Sesisfed & 176 & 70.1 \\
\hline & Nentral & 58 & 23.1 \\
\hline & Dissatisfied & 2 & 8 \\
\hline
\end{tabular}

Above data shows that many respondents are highly satisfied with Swamidharshan and quality of prasadham and many respondents were dissatisfied with the service of the guide.

\section{RESULTS AND DISCUSSION}

- It was found that $61 \%$ of the respondents were male and $39 \%$ of the pilgrims were female. It was found that $72.5 \%$ of the respondents were in the age group of 21-30 years and $5.6 \%$ of the respondents are above 40 years.

○ It was found that $85.5 \%$ of the unmarried respondents

Published By: 
were taken for this study and $15.5 \%$ of the married respondents.

It was found that $74.5 \%$ of the respondents consist of 3-4 family members and $6.4 \%$ of the respondents consist of above 6 members in their family.

- It was found that $87.6 \%$ of the respondents are from Tamilnadu and $0.8 \%$ of the respondents are from Madhya Pradesh.

- It was found that, $48.6 \%$ of the respondent's salary in the range of $41000-50000$ and $8 \%$ of the respondent's salary in the range of 50000[13]-[15].

○ It was found that $72.9 \%$ of the respondents opined leisure tour and $2.8 \%$ of the respondents opined recreation with regard to purpose of tour.

- It was found that $53 \%$ of the respondents prefer homestay and $47 \%$ of the respondents prefer hotel/resort.

- It was found that $47.8 \%$ of the respondents prefer car and $8.4 \%$ of the respondents prefer van to reach the big temple.

○ It was found that $62.9 \%$ of the respondent's tour for several times a year and $15.1 \%$ of the respondent's tour for every few years.

○ It was found that $61.8 \%$ of the respondents prefer general queue and $2.4 \%$ of the respondents prefer pass.

$\circ$ It was found that $57.4 \%$ of the respondents accompanied with their friends and $1.6 \%$ of the respondents accompanied with their partner.

○ It was found that $66.9 \%$ of the respondents are highly satisfied and $0.4 \%$ of the respondents are neutral with regard to swamidarshan[16]-[18].

- It was found that $61.4 \%$ of the respondents are highly satisfied and $2.4 \%$ of the respondents are dissatisfied with regard to quality of prasadam.

○ It was found that $45.4 \%$ of the respondents are highly satisfied and $12.4 \%$ of the respondents are neutral with regard to basic facility.

○ It was found that $56.2 \%$ of the respondents are satisfied and $0.8 \%$ of the respondents are highly dissatisfied with regard to service of the guide[19]-[22].

○ It was found that $70.1 \%$ of the respondents are satisfied and $0.8 \%$ of the respondents are highly dissatisfied with regard to service of priest

\section{SUGGESTIONS}

- It is suggested to the respective officials of Big Temple to improve the basic facilities like accommodation, restaurants, health care centres and ATM facilities near the temple.

- It is suggested to the respective officials of Big Temple to improve the genuineness and decency of the tourist guides in order to provide proper services to pilgrims.

- It is suggested to the respective officials of Big Temple to improve the knowledge of the tourist guide to provide proper information to the pilgrims.

- It is suggested to the respective officials of Big Temple to provide fan facilities in the required places inside the temple to make the pilgrims feel comfortable[23]-[25].

- It is suggested to the respective officials of Big Temple to improve the safety towards path of restrooms.

- It is suggested to the respective officials of Big Temple to provide online reservation system for swami dharshan.

- It is suggested to the respective officials of Big Temple to install the $\mathrm{Wi}-\mathrm{Fi}$ facilities provided by the government.

\section{CONCLUSION}

The tourism industry is important for any country's economic development. Among the pilgrimage tourists, most of them are giving preference to Big Temple, in terms of tour at southern states. In order to provide the tourists with better experience, the government is trying to sophisticate them with more facilities. This study's findings will definitely be helpful to officials to identify the area which needs attention. It is also important to safeguard the interests of both locals and the tourists.

\section{REFERENCES}

1) Vasanthi, S. \& Rabiyathul Basariya, S. 2019, "Influence of value analysis and cross training in industry", International Journal of Engineering and Advanced Technology, vol. 8, no. 6, pp. 1810-1811.

2) Velvizhi, R., Sri Gowtham, S. \& Jeya Priya, D. 2019, "Examination of early feedbacks for effective product retailing on E-commerce websites", International Journal of Engineering and Advanced Technology, vol. 8, no. 6 Special Issue 2, pp. 703-706.

3) Anuradha, C., Pothumani, S. \& Kavitha, R. 2019, "A novel method towards E-commerce", International Journal of Engineering and Advanced Technology, vol. 8, no. 6 Special Issue 2, pp. 535-538.

4) Thomas, J. \& Rabiyathul Basariya, S. 2019, "A study on the issues of financial ratio analysis", Indian Journal of Public Health Research and Development, vol. 10, no. 3, pp. 1079-1081.

5) Ramachandran, S. \& Rabiyathul Basariya, S. 2019, "Online marketing study on customer satisfaction and relationship", Indian Journal of Public Health Research and Development, vol. 10, no. 3, pp. 1072-1078.

6) Priya, R., Vinothini, G. \& Cor Jesu, C.D. 2019, "The mentor-protégé relationship for professional growth", Journal of Advanced Research in Dynamical and Control Systems, vol. 11, no. 9 Special Issue, pp. 1110-1119.

7) Jannifer Rani, N., Bina Pani, S. \& Nimisha, N.S. 2019, "A study on money back polices available in LIC", Journal of Advanced Research in Dynamical and Control Systems, vol. 11, no. 9 Special Issue, pp. 833-839.

8) Saillaja, V., Jhansi Rani, K. \& Catherine, R. 2019, "Global marketing management planning and organization", Journal of Advanced Research in Dynamical and Control Systems, vol. 11, no. 9 Special Issue, pp. 489-493.

9) Saillaja, V., Jhansi Rani, K. \& Catherine, R. 2019, "The new phase of marketing information system", Journal of Advanced Research in Dynamical and Control Systems, vol. 11, no. 9 Special Issue, pp. 482-488.

10) Thoufiqulla \& Raju, D.V. 2019, "Perception of indian investor towards investment in mutual funds with special reference to mip funds", Journal of Advanced Research in Dynamical and Control Systems, vol. 11, no. 5, pp. 177-183.

11) Jasmine, K.R.M. \& Basariya, S.R. 2018, "A study on the customers benefits on mutual funds", International Journal of Civil Engineering and Technology, vol. 9, no. 4, pp. 45-48

12) Vasanthi, S. \& Basariya, S.R. 2019, "Pros and cons of on the job training versus off the job training", International Journal of Scientific and Technology 
Research, vol. 8, no. 10, pp. 671-674.

13) Pavithra, J. \& Ganesan, M. 2016, "A study on awareness and impact of micro-financial schemes", International Journal of Applied Business and Economic Research, vol. 14, no. 8, pp. 5449-5460.

14) Pavithra, J., Dilli Babu, P. \& Ambuli, T.V. 2014, "A study on budgetary control at Maruti Service Masters, Chennai", International Journal of Applied Business and Economic Research, vol. 12, no. 2, pp. 151-161.

15) Gunaraja, T.M. \& Venkatrama Raju, D. 2018, "Determining factors of organisational climate with reference to leadership styles", International Journal of Mechanical Engineering and Technology, vol. 9, no. 9, pp. 1327-1332.

16) Gunaraja, T.M. \& Venkatrama Raju, D. 2018, "The role of job satisfaction and training of employees in determining organisational climate of a selected industry", International Journal of Civil Engineering and Technology, vol. 9, no. 8, pp. 1266-1269.

17) Aarathy, T.S. \& Raju, D.V. 2018, "Performance appraisal and its effects on employees with respect to it sector in Chennai city", International Journal of Civil Engineering and Technology, vol. 9, no. 6, pp. 1535-1538.

18) Aarathy, T.S. \& Raju, D.V. 2018, "Employee perception towards performance appraisal system in IT sector", International Journal of Mechanical Engineering and Technology, vol. 9, no. 5, pp. 131-135.

19) Porselvi, W., Jublee, D. \& Sivanesan, G. 2018, "A study on factors influencing adoption of technology and innovation in banking industry, tamilnadu, India", International Journal of Mechanical Engineering and Technology, vol. 9, no. 5, pp. 789-800.

20) Akessa, G.M. and Dhufera, A.G., 2015. Factors That Influences Students Academic Performance: A Case of Rift Valley University, Jimma, Ethiopia. Journal of Education and Practice, 6(22), pp.55-63.

21) Miller, G. and Shih, C.C., 1999. A faculty assessment of the academic rigor of on-and off-campus courses in agriculture. Journal of Agricultural Education, 40, pp.57-65.

22) Tsinidou, M., Gerogiannis, V. and Fitsilis, P., 2010. Evaluation of the factors that determine quality in higher education: an empirical study. Quality Assurance in education, 18(3), pp.227-244.

23) Farooq, M.S., Chaudhry, A.H., Shafiq, M. and Berhanu, G., 2011. Factors affecting students' quality of academic performance: a case of secondary school level. Journal of quality and technology management, 7(2), pp.1-14.

24) Fitsilis, P., Gerogiannis, V. and Anthopoulos, L., 2014. Ontologies for software project management: a review. Journal of Software Engineering and Applications, 7(13), p.1096.

25) Adams, J.D. and Jaffe, A.B., 1996. Bounding the effects of R\&D: an investigation using matched establishment-firm data(No. w5544). National bureau of economic research.

\section{AUTHORS PROFILE}

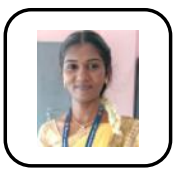

G. Vinothini Assistant Professor, Department of Science and Humanities, Bharath Institute of Higher Education and Research, Chennai , India.

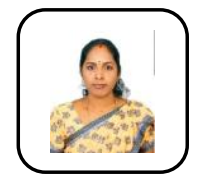

R. Priya Assistant Professor, Department of Science and Humanities, Bharath Institute of Higher Education and Research, Chennai, India.

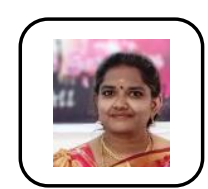

S. Jayanthy Assistant Professor, Department of Science and Humanities, Bharath Institute of Higher Education and Research, Chennai, India. 